Article

\title{
The Dynamic Effects of Isosteviol on Insulin Secretion and Its Inability to Counteract the Impaired $\beta$-Cell Function during Gluco-, Lipo-, and Aminoacidotoxicity: Studies In Vitro
}

\author{
Wenqian Gu, Andreas Rebsdorf, Kjeld Hermansen, Søren Gregersen and Per Bendix Jeppesen * \\ Department of Endocrinology and Internal Medicine, Aarhus University Hospital, Tage-Hansens Gade 2, \\ 8000 Aarhus C, Denmark; gu.wen.qian@clin.au.dk (W.G.); andreas.lund.rebsdorf@post.au.dk (A.R.); \\ kjeld.hermansen@aarhus.rm.dk (K.H.); soeren.gregersen@aarhus.rm.dk (S.G.) \\ * Correspondence: per.bendix.jeppesen@clin.au.dk; Tel.: +45-78-46-77-35
}

Received: 7 December 2017; Accepted: 24 January 2018; Published: 26 January 2018

\begin{abstract}
Isosteviol (ISV), a diterpene molecule, is an isomer of the backbone structure of a group of substances with proven antidiabetic capabilities. The aim of this study was to investigate if ISV elicits dynamic insulin release from pancreatic islets and concomitantly is able to ameliorate gluco-, lipo-, and aminoacidotoxicity in clonal $\beta$-cell line (INS-1E) in relation to cell viability and insulin secretion. Isolated mice islets placed into perifusion chambers were perifused with $3.3 \mathrm{mM}$ and $16.7 \mathrm{mM}$ glucose with/without $10^{-7} \mathrm{M}$ ISV. INS-1E cells were incubated for $72 \mathrm{~h}$ with either $30 \mathrm{mM}$ glucose, $1 \mathrm{mM}$ palmitate or $10 \mathrm{mM}$ leucine with or without $10^{-7} \mathrm{M}$ ISV. Cell viability was evaluated with a Cytotoxic Fluoro-test and insulin secretion was measured in Krebs-Ringer Buffer at $3.3 \mathrm{mM}$ and $16.7 \mathrm{mM}$ glucose. In the presence of $3.3 \mathrm{mM}$ glucose, $10^{-7} \mathrm{M}$ ISV did not change basal insulin secretion from perifused islets. However, at a high glucose level of $16.7 \mathrm{mM}, 10^{-7} \mathrm{M}$ ISV elicited a 2.5-fold increase (-ISV: $109.92 \pm 18.64 \mathrm{ng} / \mathrm{mL}$ vs. +ISV: $280.15 \pm 34.97 \mathrm{ng} / \mathrm{mL}$; $p<0.01$ ). After $72 \mathrm{~h}$ gluco-, lipo-, or aminoacidotoxicity in INS-1E cells, ISV treatment did not significantly affect cell viability (glucotoxicity, -ISV: $19.23 \pm 0.83 \%,+$ ISV: $18.41 \pm 0.90 \%$; lipotoxicity, -ISV: $70.46 \pm 3.15 \%$, +ISV: $65.38 \pm 2.81 \%$; aminoacidotoxicity: - ISV: $8.12 \pm 0.63 \%$; +ISV: $7.75 \pm 0.38 \%$, all nonsignificant). ISV did not improve impaired insulin secretion (glucotoxicity, -ISV: $52.22 \pm 2.90 \mathrm{ng} / \mathrm{mL}$, +ISV: $47.24 \pm 3.61 \mathrm{ng} / \mathrm{mL}$; lipotoxicity, -ISV: $19.94 \pm 4.10 \mathrm{ng} / \mathrm{mL}$, +ISV: $22.12 \pm 3.94 \mathrm{ng} / \mathrm{mL}$; aminoacidotoxicity: -ISV: $32.13 \pm 1.00 \mathrm{ng} / \mathrm{mL} ;+$ ISV: $30.61 \pm 1.54 \mathrm{ng} / \mathrm{mL}$, all nonsignificant). In conclusion, ISV acutely stimulates insulin secretion at high but not at low glucose concentrations. However, ISV did not counteract cell viability or cell dysfunction during gluco-, lipo-, or aminoacidotoxicity in INS-1E cells.
\end{abstract}

Keywords: isosteviol; steviol glycosides; insulin secretion; glucotoxicity; lipotoxicity; aminoacidotoxicity; mouse pancreatic islets; INS-1E cells

\section{Introduction}

Type 2 diabetes (T2D) continues to be a leading cause of death and mortality worldwide. It is characterized by hyperglycemia and frequently accompanied by hyperlipidemia and slightly elevated circulating amino acid levels. Inadequate levels of plasma insulin elevate hepatic glucose production, reduce insulin-mediated glucose uptake in skeletal muscle, and increase free fatty acid mobilization from adipose tissue, which promote the deterioration of glycemic control [1]. The total amount of released insulin in plasma depends on pancreatic $\beta$-cell proliferation and function [2], which plays a key role in T2D disease progression $[3,4]$. 
Chronic exposure to abnormally high blood glucose levels (glucotoxicity) promotes oxidative stress [5,6]. Subsequently, the adaptive antioxidant response impairs glucose-derived reactive oxygen species (ROS) signaling and glucose-stimulated insulin secretion (GSIS). Over time, this can perpetuate impaired pancreatic $\beta$-cell function and decreased $\beta$-cell mass $[7,8]$. Studies have reported that glucotoxicity negatively regulates insulin gene expression by decreasing insulin transcription factors, with pancreatic duodenal homeobox factor 1, BETA/NeuroD, and RIPE3b1/MafA included [5,9-12]. Kowluru et al. (2017) proposed that glucose toxicity induces inappropriate movement of the unprenylated yet constitutively active $G$ protein Rac1, leading to $\beta$-cell apoptosis and dysfunction [13].

Prolonged exposure to high concentrations of palmitate has detrimental effects on $\beta$-cell viability and function [14-18], possibly mediated by endoplasmic reticulum stress [19], increased ROS [20,21], impaired mitochondrial functions [22,23], altered acetylation of multiple proteins [24]. We have previously shown that long-term exposure to high lipid concentrations (lipotoxicity) causes a series of alteration in pancreatic islets including relatively elevated glucagon secretion, decreased insulin secretion, loss of $\alpha$-cell sensitivity to glucose, and an accumulation of triglycerides [25].

We have also demonstrated that chronic exposure to elevated levels of leucine and proline (aminoacidotoxicity) induces $\beta$-cell dysfunction, with increased basal insulin secretion and decreased GSIS in both isolated pancreatic islets and clonal $\beta$-cells [26-28]. Interestingly there is an association between high-protein intake and impaired glucose tolerance, insulin resistance, and T2D [29-31]. More over, during obesity and insulin resistance, high circulating levels of amino acids, e.g., leucine, proline, and valine, are seen [31].

Isosteviol (ISV) is mainly obtained by acid hydrolysis of stevioside, the sweet food additive extracted from the plant Stevia Rebaudiana Bertoni (Bertoni). Studies have shown that ISV possesses various biological activities including anti-hyperglycemic, anti-hypertensive, anti-tumor, anti-inflammatory, and antioxidant effects [32]. We have shown that ISV improves glucose and insulin sensitivity, lowers plasma triglycerides, lowers weight in diabetic KKAy mice, and markedly changes the gene expression profile of key insulin regulatory genes [33,34]. Additionally, we found evidence that ISV counteracts $\alpha$-cell hypersecretion and contributes to changes in the expression of key genes after long-term exposure to palmitate [35].

In the present study, we tried to mimic T2D conditions in clonal $\beta$-cell line (INS-1E) by inducing gluco-, lipo-, or aminoacidotoxicity, and tested whether ISV could counteract the detrimental effects observed. We also wanted to investigate the dynamic insulin secretion elicited by ISV from pancreatic mouse islets.

\section{Materials and Methods}

\subsection{Materials}

Tissue and cell culture medium RPMI 1640 was obtained from GIBCO BRL (Paisley, UK). Guinea pig anti-porcine insulin antibody, mono- ${ }^{-125} \mathrm{I}$-(Tyr A14)-labeled human insulin, and porcine insulin were from Novo Nordisk (Bagsvaerd, Denmark). Collagenase P was obtained from Boehringer Mannheim GmbH (Mannheim, Germany) and Hanks' balanced salt solution (HBSS), bovine serum albumin (BSA), and other chemicals were obtained from Sigma Chemical (St. Louis, MO, USA). ISV was purchased from Wako Pure Chemical Industries (Tokyo, Japan) and was added to the medium from a stock solution $\left(10^{-2} \mathrm{M}\right)$ prepared in $99 \%$ ethanol.

$50 \mathrm{mM}$ palmitic acid: Palmitic acid (Sigma) was prepared by dissolving and heating equal molar amounts of $\mathrm{NaOH}$, supplemented with distilled water, to obtain a concentration of $100 \mathrm{mM}$. It was further diluted with 10\% BSA (fatty acid free) to $50 \mathrm{mM}$ fatty acid, with $5 \% \mathrm{BSA}$. The stock solution was frozen at $-20^{\circ} \mathrm{C}$ until usage.

Modified Krebs-Ringer Buffer (M-KRB): $125 \mathrm{mM} \mathrm{NaCl}, 1.2 \mathrm{mM} \mathrm{MgCl}, 5.9 \mathrm{mM} \mathrm{KCl}, 1.28 \mathrm{mM}$ $\mathrm{CaCl}_{2}, 25 \mathrm{mM}$ 4-(2-hydroxyethyl)-1-piperazineethanesulfonic acid (HEPES), $5.0 \mathrm{mM} \mathrm{NaHCO}_{3}$ (pH 7.4; 
All Sigma). SYTO 24 solution: 5 mM SYTO 24 green fluorescent nucleic acid stain (molecular probes, Invitrogen, Eugene, OR, USA) in dimethyl sulfoxide was diluted to a final concentration of $0.01 \mathrm{mM}$.

\subsection{Isolation of Islets}

Pancreatic islets were isolated from adult female NMRI mice (Taconic, Ry, Denmark) weighing 22 to $25 \mathrm{~g}$ by the collagenase digestion technique, as described previously [36,37]. Briefly, after the mice were anaesthetized with pentobarbital intraperitoneally, a midline laparotomy was applied and the distal end of the common bile duct was clamped at the papilla vateri. Thereafter, the hepatic duct was cannulated and $3 \mathrm{~mL}$ of ice-cold HBSS containing $0.3 \mathrm{mg} / \mathrm{mL}$ of Collagenase $\mathrm{P}$ was injected into the duct system of the pancreas. The whole pancreas was removed and then placed in a test tube in water bath at $37^{\circ} \mathrm{C}$ for $19 \mathrm{~min}$. After being washed three times with HBSS, the islets were hand-picked under a stereomicroscope and immediately transferred to RPMI 1640 medium and incubated overnight. Islets for perifusion studies were obtained from 12 20 mice to compensate for inter-individual differences.

\subsection{Perifusion of Islets}

After overnight culture, the islets were rinsed twice with a M-KRB supplemented with $3.3 \mathrm{mM}$ glucose and $0.1 \%$ BSA. In the perifusion experiments, 30 pre-incubated islets were transferred to each of the perifusion chambers [37]. The experiments were designed as follows: (1) 10-min pre-perifusion at $3.3 \mathrm{mM}$ glucose; (2) 20-min perifusion at $3.3 \mathrm{mM}$ glucose with/without ISV $\left(10^{-7} \mathrm{M}\right)$; (3) $40-\mathrm{min}$ wash-out at $3.3 \mathrm{mM}$ glucose; (4) 20 -min perifusion at $16.7 \mathrm{mM}$ glucose with/without ISV $\left(10^{-7} \mathrm{M}\right)$; (5) 40-min wash-out at $3.3 \mathrm{mM}$ glucose; (6) 20-min perifusion at $16.7 \mathrm{mM}$ glucose with $0.1 \mathrm{mmol} / \mathrm{L}$ carbamylcholine (Sigma). The flow rate was $75 \mu \mathrm{L} / \mathrm{min}$. Samples were collected every $2 \mathrm{~min}$.

\subsection{Culture of INS-1E Cells}

INS-1E cells (a generous gift from Prof. Claes B. Wollheim, Geneva, Switzerland) [38] with passage numbers between 70-89 were cultured in RPMI 1640 medium containing $11.1 \mathrm{mM}$ D-glucose at $37{ }^{\circ} \mathrm{C}$ in a humidified atmosphere containing $95 \%$ air and $5 \% \mathrm{CO}_{2}$. The medium was supplemented with: $10 \%$ fetal bovine serum, $100 \mathrm{IU} / \mathrm{mL}$ penicillin, $100 \mu \mathrm{g} / \mathrm{mL}$ streptomycin, $10 \mathrm{mM}$ HEPES, and $5 \mu \mathrm{M}$ 2-mercaptoethanol. The cells were passaged weekly.

\subsection{Viability of INS-1E Cells}

INS-1E cells were seeded in 96-well Black Visiplate TC plates (Wallac Oy, Turku, Finland) at a density of $3 \times 10^{4}$ cells/well in $100 \mu \mathrm{L}$ medium. The cells were allowed to adhere overnight. Thereafter, they were treated and cultured with different concentrations of glucose, palmitic acid, and leucine with/without $10^{-7} \mathrm{M}$ ISV or $10^{-7} \mathrm{M}$ Glucagon-like peptide-1 (GLP-1). After $72 \mathrm{~h}$, the number of dead cells in each well was calculated using a fluorometric assasy kit based on the cell lysis and staining method (Cytotoxic Fluoro-test Wako; Wako Pure Chemical Industries, Osaka, Japan) in the FLUOstar Galaxy (BMG, Ramcon, Denmark).

\subsection{Insulin Secretion from INS-1E Cells}

The INS-1E cells were seeded in 24-well Black Visiplate TC (Wallac Oy, Turku, Finland) plates at a density of $3.0 \times 10^{5}$ cells/well in $1 \mathrm{~mL}$ medium. After adhering overnight, the cells were cultured in RPMI 1640 with different concentrations of glucose, palmitic acid, and leucine with/without $10^{-7} \mathrm{M}$ ISV or $10^{-7} \mathrm{M}$ GLP-1. After $72 \mathrm{~h}$ of incubation, the cells were pre-incubated with M-KRB supplemented with $3.3 \mathrm{mM}$ glucose and $0.1 \%$ BSA for $15 \mathrm{~min}$ and then the cells were incubated in $1 \mathrm{~mL}$ M-KRB containing 3.3 or $16.7 \mathrm{mM}$ glucose for $1 \mathrm{~h}$. Subsequently, supernatants ( $300 \mu \mathrm{L})$ were collected, centrifuged, and $200 \mu \mathrm{L}$ were kept at $-20^{\circ} \mathrm{C}$ for insulin analysis. After the secretion study, the number of cells was estimated using nuclear staining with $0.01 \mathrm{mM}$ SYTO 24 reagent $(20 \mu \mathrm{L} /$ well $)$ and measured by FLUOstar Galaxy. Insulin levels were normalized to cell number. 


\subsection{Insulin Assay}

Insulin was analyzed by radioimmunoassay using guinea pig anti-porcine insulin antibody (Novo Nordisk, Bagsvaerd, Denmark). Mono- ${ }^{125}$ I-(Tyr A14)-labeled human insulin (Novo Nordisk) was used as tracer and rat insulin (Novo Nordisk) was used as a standard. Ethanol was added to separate bound and free radioactivity. The inter- and intra-assay variation coefficients were both less than 5\%.

\section{Statistical Analysis}

All data analysis was performed with GraphPad Prism Software Version 7.0 (GraphPad Software, San Diego, CA, USA). Statistical significance between two groups was evaluated using unpaired Student's $t$-test. Data are presented as the mean \pm standard error of the meam (SEM); $p$-values $<0.05$ were considered significant.

\section{Results}

\subsection{Effects of ISV on the Dynamic of Insulin Release from Perifused Mouse Islets}

In the presence of $3.3 \mathrm{mM}$ glucose, the addition of ISV did not change basal insulin secretion. As expected, a biphasic insulin response was found when glucose level was increased from 3.3 to $16.7 \mathrm{mM}$. Figure 1 shows that in the presence of high levels of glucose $(16.7 \mathrm{mM})$, ISV $\left(10^{-7} \mathrm{M}\right)$ elicited a pronounced and sustained 2.5-fold ( $p=0.0016)$ monophasic increase in insulin release. At 130-150 min, the insulin AUC (area under the curve) increased 2-fold $(p=0.0058)$ in the ISV group compared to the control.

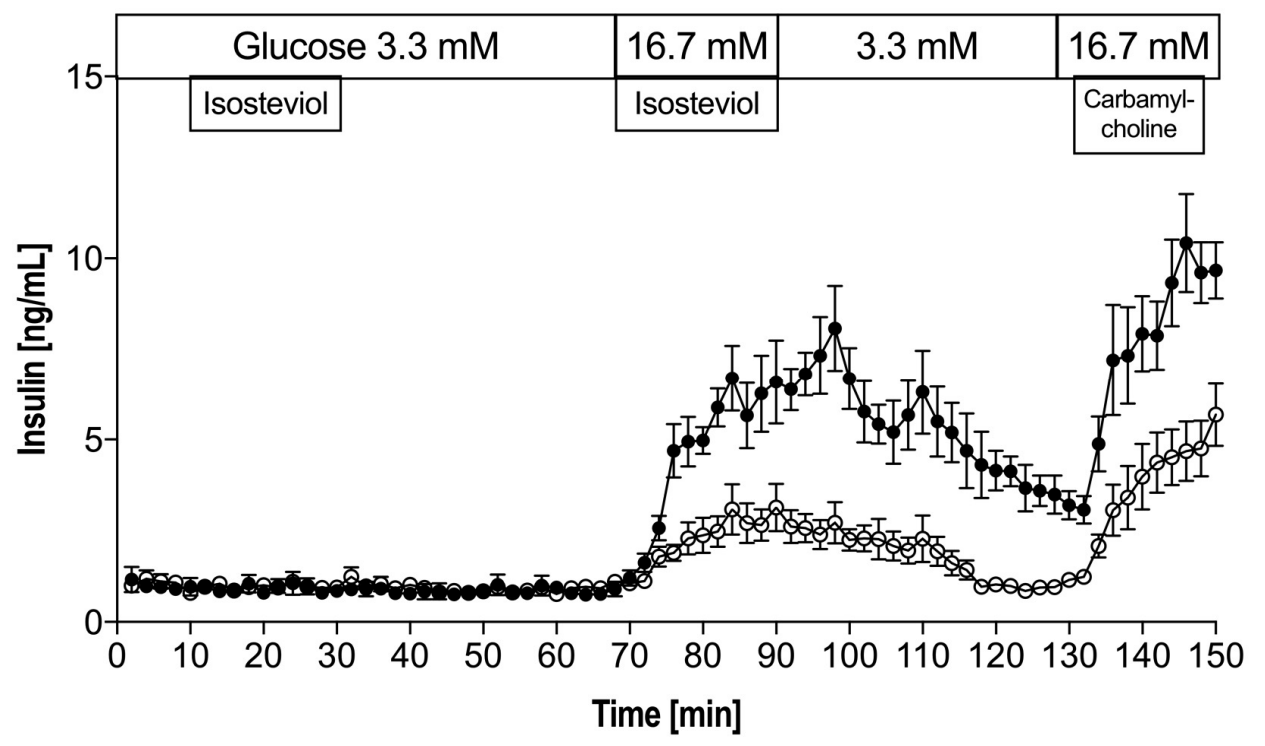

Figure 1. Insulin secretion from mouse islets in perifusion experiments in the absence (control $\bigcirc$ ) or presence (intervention $\bullet$ ) of $10^{-7} \mathrm{M}$ isosteviol (ISV) at $3.3 \mathrm{mM}$ and $16.7 \mathrm{mM}$ glucose. Each curve represents the average \pm standard error of the meam (SEM) of six perifusion experiments, each containing 30 islets. Experiments were finished off with carbamylcholine as a positive control at $16.7 \mathrm{mM}$ glucose.

\subsection{Impact of Gluco-, Lipo-, and Aminoacidotoxicity on the Viability of INS-1E Cells}

\subsubsection{Glucotoxicity}

INS-1E cells were challenged with low $(5.5 \mathrm{mM})$ and high $(30 \mathrm{mM})$ glucose for $72 \mathrm{~h}$ with and without $10^{-7} \mathrm{M}$ ISV and $10^{-7} \mathrm{M}$ GLP-1. A significant increase of cell death rate was discovered at high glucose levels compared to the control group (11.1 mM glucose), while no change was found at low glucose levels. However, no significant change was induced by co-incubation with either $10^{-7} \mathrm{M} \mathrm{ISV}$ or $10^{-7}$ M GLP-1(Figure 2). 


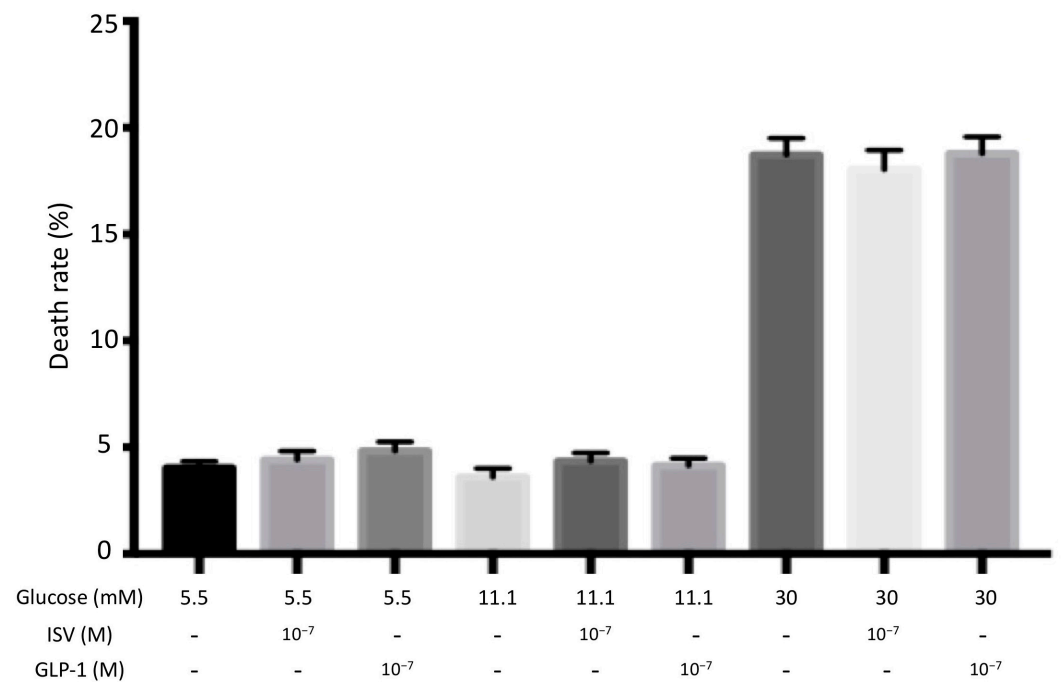

Figure 2. Effects $10^{-7} \mathrm{M}$ ISV and $10^{-7} \mathrm{M}$ Glucagon-like peptide-1 (GLP-1) on cell death rate in glucose-treated INS-1E cells. We measured cell death rate following $72 \mathrm{~h}$ of incubation with or without $10^{-7} \mathrm{M}$ ISV $/ 10^{-7} \mathrm{M}$ GLP-1, in the presence of $5.5 \mathrm{mM}, 11.1 \mathrm{mM}$, or $30 \mathrm{mM}$ glucose. Data are presented as the mean \pm SEM of 28 samples per group from three independent experiments.

\subsubsection{Lipotoxicity}

Figure 3 shows the effect of $10^{-7} \mathrm{M}$ ISV and $10^{-7} \mathrm{M}$ GLP- 1 on the viability of INS-1E cells treated with $0.1 \mathrm{mM}, 0.5 \mathrm{Mm}$, or $1 \mathrm{mM}$ palmitic acid. Cell death level was significantly increased to $36 \%$ at $0.5 \mathrm{mM}$ palmitic acid, and to $70 \%$ at $1 \mathrm{mM}$ palmitic acid. No significant difference was found after co-incubation with either $10^{-7} \mathrm{M}$ ISV or $10^{-7}$ M GLP-1.

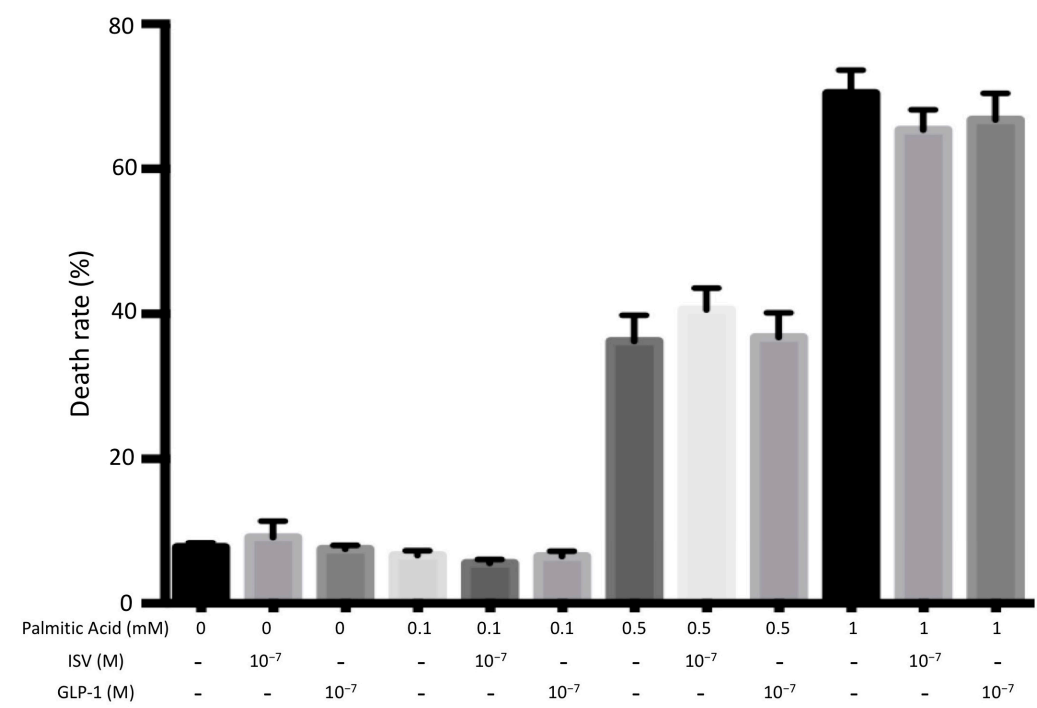

Figure 3. Effects $10^{-7} \mathrm{M}$ ISV and $10^{-7} \mathrm{M}$ GLP-1 on cell death rate in palmitic acid-treated INS-1E cells. We measured cell death rate following $72 \mathrm{~h} \mathrm{OF}$ incubation with or without $10^{-7} \mathrm{M}$ ISV and $10^{-7} \mathrm{M}$ GLP-1, in the medium containing $0.1 \mathrm{mM}, 0.5 \mathrm{mM}$, or $1 \mathrm{mM}$ palmitic acid. Data are presented as the mean \pm SEM of 28 samples per group from three independent expriments. The vehicle of $0 \mathrm{mM}$ palmitic acid is equivalent to that of $0.5 \mathrm{mM}$ palmitic acid. 


\subsubsection{Aminoacidotoxicity}

As shown in Figure 4, cell death rates were slightly increased when INS-1E cells were exposed to $1 \mathrm{mM}$ and $10 \mathrm{mM}$ leucine. However, no significant change was induced by co-incubation with either $10^{-7} \mathrm{M}$ ISV or $10^{-7} \mathrm{M}$ GLP-1.

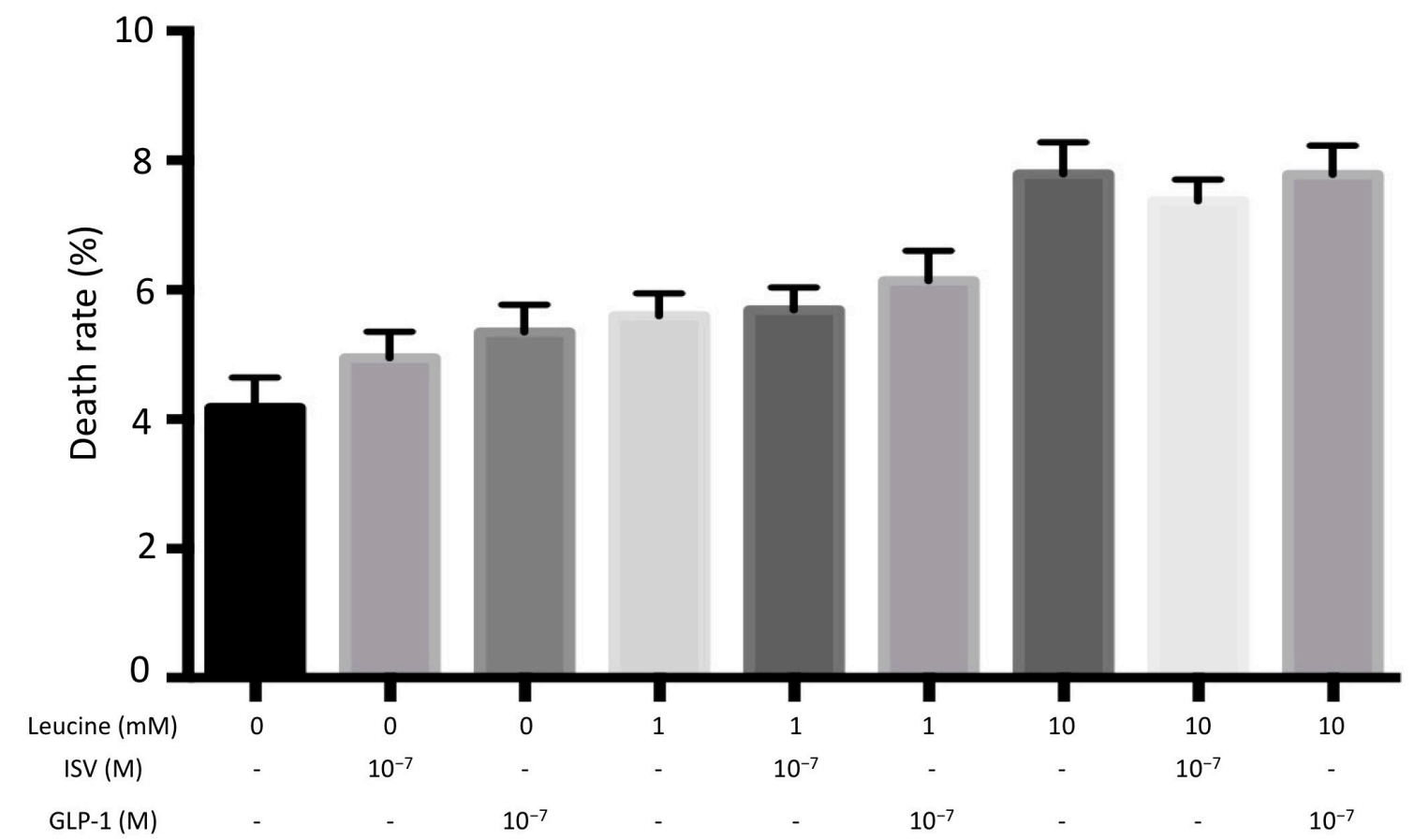

Figure 4. Effects of $10^{-7} \mathrm{M}$ ISV and $10^{-7} \mathrm{M}$ GLP-1 on cell death rate in leucine-treated INS-1E cells. We measured cell death rate following $72 \mathrm{~h}$ of incubation with or without $10^{-7} \mathrm{M}$ ISV and $10^{-7} \mathrm{M}$ GLP-1, in the medium containing $1 \mathrm{mM}$ or $10 \mathrm{mM}$ leucine. Data are presented as the mean $\pm \mathrm{SEM}$ of 28 samples per group from three independent experiments.

\subsection{Impact of Gluco-, Lipo-, and Aminoacidotoxicity on Insulin Secretion of INS-1E Cells}

\subsubsection{Glucotoxicity}

Figure 5 shows that at $3.3 \mathrm{mM}$ glucose, BIS (basal insulin secretion) from INS-1E cells remained unchanged after $72 \mathrm{~h}$ of incubation with $5.5 \mathrm{mM}$ and $30 \mathrm{mM}$ glucose. High glucose $(16.7 \mathrm{mM})$ stimulated insulin secretion increased after $72 \mathrm{~h}$ of exposure of the cells to $5.5 \mathrm{mM}$ glucose, but decreased insulin secretion to $30 \mathrm{mM}$ glucose. Neither $10^{-7} \mathrm{M}$ ISV nor $10^{-7} \mathrm{M}$ GLP-1 elicited any significant changes from INS-1E cells incubated at $5.5 \mathrm{mM}, 11.1 \mathrm{mM}$, and $30 \mathrm{mM}$ glucose 


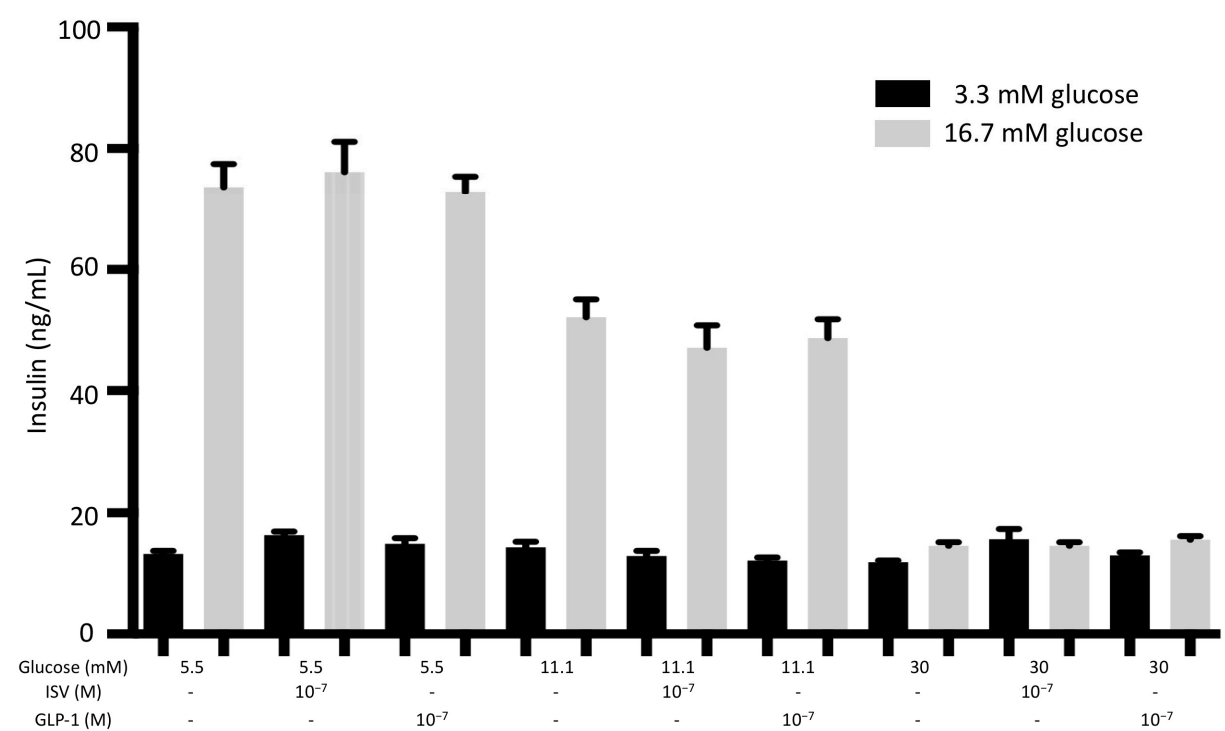

Figure 5. Effects of $10^{-7} \mathrm{M}$ ISV and $10^{-7} \mathrm{M}$ GLP-1 on insulin secretion from glucose-treated INS-1E cells. After $72 \mathrm{~h}$ of incubation with or without $10^{-7} \mathrm{M}$ ISV and $10^{-7} \mathrm{M}$ GLP-1, in the medium containing $5.5 \mathrm{mM}, 11.1 \mathrm{mM}$, or $30 \mathrm{mM}$ glucose, cells were stimulated with low $(3.3 \mathrm{mM})$ and high $(16.7 \mathrm{mM})$ glucose for $1 \mathrm{~h}$, and subsequently insulin secretion was measured. Data are presented as the mean \pm SEM of 18 samples per group from three independent experiments.

\subsubsection{Lipotoxicity}

As can be seen in Figure 6, there was no significant change in BIS at $3.3 \mathrm{mM}$ glucose from INS-1E cells after $72 \mathrm{~h}$ of incubation with $0.1 \mathrm{mM}, 0.5 \mathrm{mM}$, or $1 \mathrm{mM}$ palmitic acid. By contrast, high concentrations $(0.5 \mathrm{mM}$ and $1 \mathrm{mM})$ of palmitic acid significantly decreased insulin secretion after $72 \mathrm{~h}$. Neither $10^{-7}$ ISV nor $10^{-7}$ GLP-1 made a significant change in this situation.

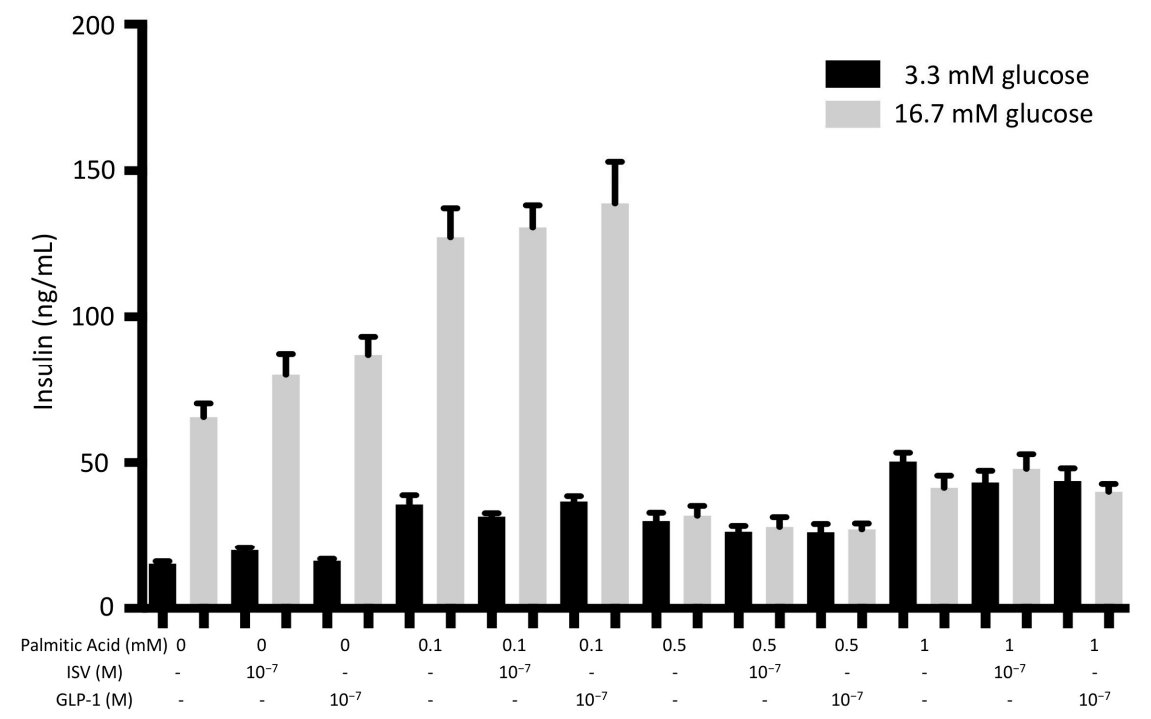

Figure 6. Effects of $10^{-7} \mathrm{M}$ ISV and $10^{-7} \mathrm{M}$ GLP-1 on insulin secretion in palmitic acid-treated INS-1E cells. After $72 \mathrm{~h}$ of incubation with or without $10^{-7} \mathrm{M}$ ISV and $10^{-7} \mathrm{M}$ GLP-1, in the medium containing $0.1 \mathrm{mM}, 0.5 \mathrm{mM}$, or $1 \mathrm{mM}$ palmitic acid, cells were stimulated at low $(3.3 \mathrm{mM})$ and high glucose $(16.7 \mathrm{mM})$ for $1 \mathrm{~h}$. Subsequently, insulin secretion was measured. Data are presented as the mean \pm SEM of 18 samples per group from three independent experiments. The vehicle of $0 \mathrm{mM}$ palmitic acid is equivalent to that of $0.5 \mathrm{mM}$ palmitic acid. 


\subsubsection{Aminoacidotoxicity}

When INS-1E cells were exposed to $1 \mathrm{mM}$ or $10 \mathrm{mM}$ leucine for $72 \mathrm{~h}$, no significant effect on insulin secretion was found compared to the control group. Both $10^{-7} \mathrm{M}$ ISV and $10^{-7} \mathrm{M}$ GLP-1 showed no effect in these conditions, as illustrated in Figure 7.

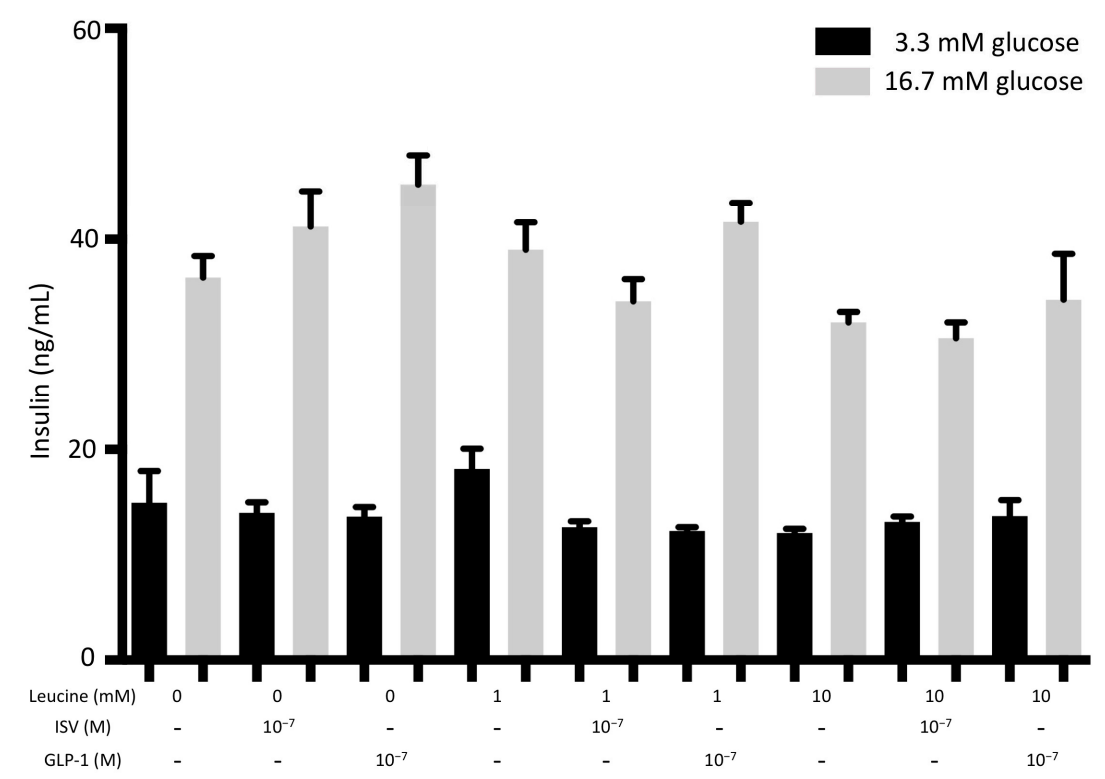

Figure 7. Effects of $10^{-7} \mathrm{M}$ ISV and $10^{-7} \mathrm{M}$ GLP-1 on insulin secretion in leucine-treated INS-1E cells. After $72 \mathrm{~h}$ of incubation with or without $10^{-7} \mathrm{M}$ ISV and $10^{-7} \mathrm{M}$ GLP-1, in the medium containing $1 \mathrm{mM}$ or $10 \mathrm{mM}$ palmitic acid, INS1-E cells were stimulated with low $(3.3 \mathrm{mM})$ and high $(16.7 \mathrm{mM})$ glucose. Subsequently, insulin secretion was measured. Data are presented as the mean \pm SEM of 18 samples per group from three independent experiments.

\section{Discussion}

Numerous studies have shown that the major steviol glycosides, stevioside and Rebaudioside A, possess anti-hyperglycemic effects [39-44]. The stevioside derivative, ISV, has a higher bioavailability and a more potent insulinotropic effect. This study is the first to demonstrate that ISV causes a dynamic insulin stimulatory effect. However, ISV is not able to counteract the toxic effects of chronic exposure of INS-1E cells to high concentrations of glucose, palmitic acid, or leucine.

T2D is a chronic metabolic disorder that results from relative insulin deficiency and insulin resistance. In T2D patients, hypoglycemia is a major safety issue that can be fatal, particularly in patients with cardiovascular diseases. The risk of hypoglycemia is one of the main reasons preventing patients from achieving optimal glucose levels $[45,46]$. The incidence of hypoglycemia is a major drawback for sulfonylureas, a classic medication towards T2D, and it has therefore been assigned a lower priority in the AACE/ACE (American Association of Clinical Endocrinologists / American College of Endocrinology) treatment algorithm for T2D [47]. There is an urgent need to identify potential new drugs that enable T2D patients to both achieve glycemic goals and avoid hypoglycemia simultaneously. Steviol glycosides seem to have this potential. In the perifusion experiment, we have demonstrated that ISV elicits a distinct monophasic insulin response, similar to what we have previously found for stevioside, Rebaudioside A, and steviol $[40,44]$. That is, ISV stimulated insulin secretion in a dose-dependent manner. It showed no insulinotropic action at a low glucose level of $3.3 \mathrm{mM}$, while it caused a clear-cut insulin release at high glucose levels. Consequently, our results indicate that ISV possesses the desired potential in the treatment of T2D, since the insulinotropic action present at high glucose levels disappears at low glucose concentrations. 
Carbamylcholine is a cholinergic agonist, which depolarizes the $\beta$-cell by the activation of the acetylcholine receptors. In the present study, carbamycholine is used as a positive control to confirm the secretory capacity of the islets. It is noteworthy that during the wash-out period at 90-130 min, the effect on ISV showed some "tale effect", that is, the effect of ISV did not vanish immediately but declined gradually toward a basic level. This may be because ISV influences a receptor (e.g., a TRPM5-related receptor) and remains bound for some time, resulting in the effect gradually disappearing. TRPM5, transient receptor potential cation channel subfamily melastatin member 5 , is a monovalent cation channel located in various human cells, including Type II taste receptor cells and pancreatic $\beta$-cells [48-50]. An increase in intracellular calcium would activate TRPM5; Philippaert K. et al. (2017) proved that the potentiation of the channel's activity by steviol glycosides modulates taste responses and insulin release, which would explain the feature of the compound being sweet and lowering blood glucose concurrently [51].

Steviol glycosides share a common aglycone core structure steviol (ent-13-hydrozykaur-16en-18-oic acid), which as mentioned could be converted to ISV through acid hydrolysis. The chemical structures of steviol and ISV are very similar, see Figure 8, indicating that their insulin-secreting effect is mostly related to their common diterpene skeleton [52].

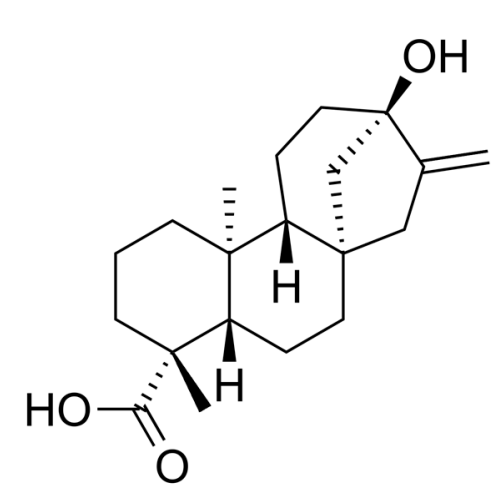

Steviol

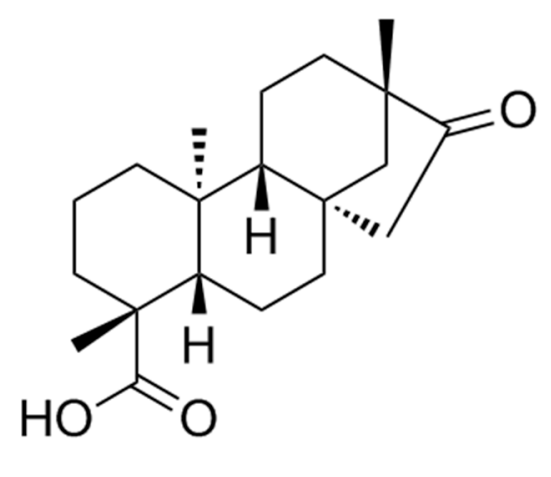

Isosteviol

Figure 8. Chemical structure of steviol and isosteviol.

As illustrated in Figures 2-4, the toxic concentrations of glucose $(30 \mathrm{mM})$, palmitate $(0.5 \mathrm{mM}$ and $1 \mathrm{mM}$ ) or leucine $(10 \mathrm{mM})$ caused INS-1E cell death, with an increasing toxic sequence: $10 \mathrm{mM}$ leucine, $30 \mathrm{mM}$ glucose, and 0.5 (or 1) $\mathrm{mM}$ palmitic acid. ISV did not counteract the detrimental effects caused by gluco-, lipo-, or aminoacidotoxicity. However, in the control groups the presence of ISV did not change cell viability, indicating the absence of cytotoxic effects of ISV and pointing to a promising safety profile of ISV.

The insulin secretion results depicted in Figures 5-7 are in line with the results from cell viability studies. When INS-1E cells were exposed to gluco- or lipotoxicity, a large portion of cells were dead and undoubtedly not functioning well. Therefore, the insulin amount released from the cells was decreased dramatically. Surprisingly, in the present study the aminoacidotoxicity was minimal since cell death was only slightly increased and insulin secretion was unaffected during high amino acid levels.

Our results suggest that ISV possesses no protective effects on INS-1E cells when exposed to gluco-, lipo-, or aminotoxicity. Interestingly, we have previously found that after nine weeks of treatment with standard chow diet plus ISV, plasma glucose was reduced by $38 \%$ in KKAy diabetic mice, of which the plasma glucose levels were about $26 \mathrm{mM}$ before the treatment [33]. The apparent discrepancy between the results from the two studies may indicate that the protective effects of ISV may not operate directly via an effect on INS-1E cells. Alternatively, INS1-E cells per se may not be sensitive to the protective effects of ISV after long-term gluco-, lipo, or aminoacidotoxicity. 
We also included glucagon-like peptide-1- (7-36) amide (GLP-1) in this study to compare the pharmacological effects of these two compounds. GLP-1, a potent incretin hormone, has been developed into an important drug for the treatment of T2D [52]. Until now, few studies have investigated the effect of GLP-1 in $\alpha$-cells regarding change in glucagon secretion and cell proliferation under gluco-, lipo-, and aminoacidotoxicity conditions, and no previous studies have compared its effect with ISV. GLP-1 and ISV seem to share a few features, e.g., both show glucose-dependent insulinotropic effects and both lower body weight. Like ISV, GLP-1 did not show significant effects on cell viability or insulin secretion during long-term gluco-, lipo-, or aminoacidotoxiciy in INS-1 cells.

Impressively, when INS-1E cells were exposed to low glucose $(5.5 \mathrm{mM})$ there was no significant influence on cell viability, whereas the insulin secretion was dramatically raised. This may reflect that the cells are more sensitive to glucose stimulation when the prevailing glucose level is relatively low. This underlines the importance of maintaining optimal glycemic control.

\section{Conclusions}

In conclusion, ISV did not increase cell death and, in this respect, it appears safe. We showed a pronounced dynamic effect of ISV on glucose-stimulated insulin secretion from mouse pancreatic islets. However, ISV does not counteract gluco-, lipo-, or aminoacidotoxicity in INS-1E cells. Further studies are required to demonstrate the antidiabetic effects of ISV and to further confirm its safety profile in humans.

Acknowledgments: The study was supported by a fully financed mobility Ph.D fellowship from Faculty of Health, Aarhus University, Denmark. The technical support from Lene Trudsø and Eva Mølgaard Jensen (Department of Endocrinology and Internal Medicine, Aarhus University Hospital) is gratefully acknowledged. Special thanks to Max N.T. Lambert for assistance with English language editing.

Author Contributions: All authors contributed to the preparation of this manuscript and approved the text.

Conflicts of Interest: The authors declare no conflict of interest. The founding sponsors had no role in the design of the study; in the collection, analyses, or interpretation of data; in the writing of the manuscript, and in the decision to publish the results.

\section{References}

1. Lebovitz, H.E. Type 2 diabetes: An overview. Clin. Chem. 1999, 45, 1339-1345. [PubMed]

2. Chen, C.; Cohrs, C.M.; Stertmann, J.; Bozsak, R.; Speier, S. Human beta cell mass and function in diabetes: Recent advances in knowledge and technologies to understand disease pathogenesis. Mol. Metab. 2017, 6, 943-957. [CrossRef] [PubMed]

3. Engelbrechtsen, L.; Andersson, E.; Roepstorff, S.; Hansen, T.; Vestergaard, H. Pharmacogenetics and individual responses to treatment of hyperglycemia in type 2 diabetes. Pharmacogenet. Genom. 2015, 25, 475-484. [CrossRef] [PubMed]

4. Høiriis Nielsen, J.; Svensson, C.; Douglas Galsgaard, E.; Møldrup, A.; Billestrup, N. Beta cell proliferation and growth factors. J. Mol. Med. 1999, 77, 62-66. [CrossRef]

5. Chen, F.; Sha, M.; Wang, Y.; Wu, T.; Shan, W.; Liu, J.; Zhou, W.; Zhu, Y.; Sun, Y.; Shi, Y.; et al. Transcription factor ets-1 links glucotoxicity to pancreatic beta cell dysfunction through inhibiting pdx-1 expression in rodent models. Diabetologia 2016, 59, 316-324. [CrossRef] [PubMed]

6. Wali, J.A.; Rondas, D.; McKenzie, M.D.; Zhao, Y.; Elkerbout, L.; Fynch, S.; Gurzov, E.N.; Akira, S.; Mathieu, C.; Kay, T.W.; et al. The proapoptotic bh3-only proteins bim and puma are downstream of endoplasmic reticulum and mitochondrial oxidative stress in pancreatic islets in response to glucotoxicity. Cell Death Dis. 2014, 5, e1124. [CrossRef] [PubMed]

7. Fu, J.; Cui, Q.; Yang, B.; Hou, Y.; Wang, H.; Xu, Y.; Wang, D.; Zhang, Q.; Pi, J. The impairment of glucosestimulated insulin secretion in pancreatic beta-cells caused by prolonged glucotoxicity and lipotoxicity is associated with elevated adaptive antioxidant response. Food Chem. Toxicol. 2017, 100, 161-167. [CrossRef] [PubMed]

8. Cernea, S.; Dobreanu, M. Diabetes and beta cell function: From mechanisms to evaluation and clinical implications. Biochem. Med. (Zagreb) 2013, 23, 266-280. [CrossRef] [PubMed] 
9. Olson, L.K.; Redmon, J.B.; Towle, H.C.; Robertson, R.P. Chronic exposure of hit cells to high glucose concentrations paradoxically decreases insulin gene transcription and alters binding of insulin gene regulatory protein. J. Clin. Investig. 1993, 92, 514-519. [CrossRef] [PubMed]

10. Olson, L.K.; Sharma, A.; Peshavaria, M.; Wright, C.V.; Towle, H.C.; Rodertson, R.P.; Stein, R. Reduction of insulin gene transcription in hit-t15 beta cells chronically exposed to a supraphysiologic glucose concentration is associated with loss of stf-1 transcription factor expression. PNAS 1995, 92, 9127-9131. [CrossRef] [PubMed]

11. Harmon, J.S.; Stein, R.; Robertson, R.P. Oxidative stress-mediated, post-translational loss of mafa protein as a contributing mechanism to loss of insulin gene expression in glucotoxic beta cells. J. Biol. Chem. 2005, 280, 11107-11113. [CrossRef] [PubMed]

12. Poitout, V.; Olson, L.K.; Robertson, R.P. Chronic exposure of betatc- 6 cells to supraphysiologic concentrations of glucose decreases binding of the ripe3b1 insulin gene transcription activator. J. Clin. Investig. 1996, 97, 1041-1046. [CrossRef] [PubMed]

13. Kowluru, A. Inappropriate movement of rac1 contributes to glucotoxicity of the islet beta-cell. Cell Cycle 2017, 16, 1387-1388. [CrossRef] [PubMed]

14. Cnop, M.; Abdulkarim, B.; Bottu, G.; Cunha, D.A.; Igoillo-Esteve, M.; Masini, M.; Turatsinze, J.V.; Griebel, T.; Villate, O.; Santin, I.; et al. Rna sequencing identifies dysregulation of the human pancreatic islet transcriptome by the saturated fatty acid palmitate. Diabetes 2014, 63, 1978-1993. [CrossRef] [PubMed]

15. Amery, C.M.; Nattrass, M. Fatty acids and insulin secretion. Diabetes Obes. Metab. 2000, 2, 213-221. [CrossRef] [PubMed]

16. El-Assaad, W.; Buteau, J.; Peyot, M.L.; Nolan, C.; Roduit, R.; Hardy, S.; Joly, E.; Dbaibo, G.; Rosenberg, L.; Prentki, M. Saturated fatty acids synergize with elevated glucose to cause pancreatic beta-cell death. Endocrinology 2003, 144, 4154-4163. [CrossRef] [PubMed]

17. Lupi, R.; Dotta, F.; Marselli, L.; Del Guerra, S.; Masini, M.; Santangelo, C.; Patane, G.; Boggi, U.; Piro, S.; Anello, M.; et al. Prolonged exposure to free fatty acids has cytostatic and pro-apoptotic effects on human pancreatic islets: Evidence that beta-cell death is caspase mediated, partially dependent on ceramide pathway, and bcl-2 regulated. Diabetes 2002, 51, 1437-1442. [CrossRef] [PubMed]

18. Lee, S.H.; Cunha, D.; Piermarocchi, C.; Paternostro, G.; Pinkerton, A.; Ladriere, L.; Marchetti, P.; Eizirik, D.L.; Cnop, M.; Levine, F. High-throughput screening and bioinformatic analysis to ascertain compounds that prevent saturated fatty acid-induced beta-cell apoptosis. Biochem. Pharmacol. 2017, 138, 140-149. [CrossRef] [PubMed]

19. Cunha, D.A.; Hekerman, P.; Ladriere, L.; Bazarra-Castro, A.; Ortis, F.; Wakeham, M.C.; Moore, F.; Rasschaert, J.; Cardozo, A.K.; Bellomo, E.; et al. Initiation and execution of lipotoxic er stress in pancreatic beta-cells. J. Cell Sci. 2008, 121, 2308-2318. [CrossRef] [PubMed]

20. Natalicchio, A.; Tortosa, F.; Labarbuta, R.; Biondi, G.; Marrano, N.; Carchia, E.; Leonardini, A.; Cignarelli, A.; Bugliani, M.; Marchetti, P.; et al. The p66Shc redox adaptor protein is induced by saturated fatty acids and mediates lipotoxicity-induced apoptosis in pancreatic beta cells. Diabetologia 2015, 58, 1260-1271. [CrossRef] [PubMed]

21. Carlsson, C.; Borg, L.A.; Welsh, N. Sodium palmitate induces partial mitochondrial uncoupling and reactive oxygen species in rat pancreatic islets in vitro. Endocrinology 1999, 140, 3422-3428. [CrossRef] [PubMed]

22. Cunha, D.A.; Igoillo-Esteve, M.; Gurzov, E.N.; Germano, C.M.; Naamane, N.; Marhfour, I.; Fukaya, M.; Vanderwinden, J.M.; Gysemans, C.; Mathieu, C.; et al. Death protein 5 and p53-upregulated modulator of apoptosis mediate the endoplasmic reticulum stress-mitochondrial dialog triggering lipotoxic rodent and human beta-cell apoptosis. Diabetes 2012, 61, 2763-2775. [CrossRef] [PubMed]

23. Barlow, J.; Jensen, V.H.; Jastroch, M.; Affourtit, C. Palmitate-induced impairment of glucose-stimulated insulin secretion precedes mitochondrial dysfunction in mouse pancreatic islets. Biochem. J. 2016, 473, 487-496. [CrossRef] [PubMed]

24. Ciregia, F.; Bugliani, M.; Ronci, M.; Giusti, L.; Boldrini, C.; Mazzoni, M.R.; Mossuto, S.; Grano, F.; Cnop, M.; Marselli, L.; et al. Palmitate-induced lipotoxicity alters acetylation of multiple proteins in clonal beta cells and human pancreatic islets. Sci. Rep. 2017, 7, 13445. [CrossRef] [PubMed]

25. Hong, J.; Jeppesen, P.B.; Hermansen, K. Effects of elevated fatty acid and glucose concentrations on pancreatic islet function in vitro. Diabetes Obes. Metab. 2009, 11, 397-404. [PubMed] 
26. Liu, Z.; Jeppesen, P.B.; Gregersen, S.; Larsen, L.B.; Hermansen, K. Chronic exposure to leucine in vitro induces beta-cell dysfunction in ins-1e cells and mouse islets. J. Endocrinol. 2012, 215, 79-88. [CrossRef] [PubMed]

27. Liu, Z.; Luo, Y.; Jeppesen, P.B.; Gregersen, S.; Hermansen, K. Amino acid-induced gene expression profiling in clonal beta-cell line ins-1e cells. Diabetes Metab. Res. Rev. 2011, 27, 120-176. [CrossRef] [PubMed]

28. Liu, Z.; Jeppesen, P.B.; Gregersen, S.; Bach Larsen, L.; Hermansen, K. Chronic exposure to proline causes aminoacidotoxicity and impaired beta-cell function: Studies in vitro. Rev. Diabet. Stud. 2016, 13, 66-78. [CrossRef] [PubMed]

29. Schulze, M.B.; Manson, J.E.; Willett, W.C.; Hu, F.B. Processed meat intake and incidence of type 2 diabetes in younger and middle-aged women. Diabetologia 2003, 46, 1465-1473. [CrossRef] [PubMed]

30. Newgard, C.B.; An, J.; Bain, J.R.; Muehlbauer, M.J.; Stevens, R.D.; Lien, L.F.; Haqq, A.M.; Shah, S.H.; Arlotto, M.; Slentz, C.A.; et al. A branched-chain amino acid-related metabolic signature that differentiates obese and lean humans and contributes to insulin resistance. Cell Metab. 2009, 9, 311-326. [CrossRef] [PubMed]

31. Tai, E.S.; Tan, M.L.; Stevens, R.D.; Low, Y.L.; Muehlbauer, M.J.; Goh, D.L.; Ilkayeva, O.R.; Wenner, B.R.; Bain, J.R.; Lee, J.J.; et al. Insulin resistance is associated with a metabolic profile of altered protein metabolism in chinese and asian-indian men. Diabetologia 2010, 53, 757-767. [CrossRef] [PubMed]

32. Testai, L.; Strobykina, I.; Semenov, V.V.; Semenova, M.; Pozzo, E.D.; Martelli, A.; Citi, V.; Martini, C.; Breschi, M.C.; Kataev, V.E.; et al. Mitochondriotropic and cardioprotective effects of triphenylphosphoniumconjugated derivatives of the diterpenoid isosteviol. Int. J. Mol. Sci. 2017, 18, 2060. [CrossRef] [PubMed]

33. Nordentoft, I.; Jeppesen, P.B.; Hong, J.; Abudula, R.; Hermansen, K. Isosteviol increases insulin sensitivity and changes gene expression of key insulin regulatory genes and transcription factors in islets of the diabetic kkay mouse. Diabetes Obes. Metab. 2008, 10, 939-949. [CrossRef] [PubMed]

34. Bertram, H.C.; Jeppesen, P.B.; Hermansen, K. An NMR-based metabonomic investigation on effects of supplementation with isosteviol or soy protein to diabetic kkay mice. Diabetes Obes. Metab. 2009, 11, 992-995. [CrossRef] [PubMed]

35. Chen, X.; Hermansen, K.; Xiao, J.; Bystrup, S.K.; O’Driscoll, L.; Jeppesen, P.B. Isosteviol has beneficial effects on palmitate-induced alpha-cell dysfunction and gene expression. PLoS ONE 2012, 7, e34361.

36. Lacy, P.E.; Kostianovsky, M. Method for the isolation of intact islets of langerhans from the rat pancreas. Diabetes 1967, 16, 35-39. [CrossRef] [PubMed]

37. Gregersen, S.; Thomsen, J.L.; Brock, B.; Hermansen, K. Endothelin-1 stimulates insulin secretion by direct action on the islets of langerhans in mice. Diabetologia 1996, 39, 1030-1035. [CrossRef] [PubMed]

38. Merglen, A.; Theander, S.; Rubi, B.; Chaffard, G.; Wollheim, C.B.; Maechler, P. Glucose sensitivity and metabolism-secretion coupling studied during two-year continuous culture in INS-1E insulinoma cells. Endocrinology 2004, 145, 667-678. [CrossRef] [PubMed]

39. Chatsudthipong, V.; Muanprasat, C. Stevioside and related compounds: Therapeutic benefits beyond sweetness. Pharmacol. Ther. 2009, 121, 41-54. [CrossRef] [PubMed]

40. Jeppesen, P.B.; Gregersen, S.; Poulsen, C.R.; Hermansen, K. Stevioside acts directly on pancreatic beta cells to secrete insulin: Actions independent of cyclic adenosine monophosphate and adenosine triphosphate-sensitive $\mathrm{K}^{+}$-channel activity. Metabolism 2000, 49, 208-214. [CrossRef]

41. Jeppesen, P.B.; Gregersen, S.; Alstrup, K.K.; Hermansen, K. Stevioside induces antihyperglycaemic, insulinotropic and glucagonostatic effects in vivo: Studies in the diabetic goto-kakizaki (GK) rats. Phytomedicine 2002, 9, 9-14. [CrossRef] [PubMed]

42. Jeppesen, P.B.; Gregersen, S.; Rolfsen, S.E.; Jepsen, M.; Colombo, M.; Agger, A.; Xiao, J.; Kruhoffer, M.; Orntoft, T.; Hermansen, K. Antihyperglycemic and blood pressure-reducing effects of stevioside in the diabetic goto-kakizaki rat. Metabolism 2003, 52, 372-378. [CrossRef] [PubMed]

43. Jeppesen, P.B.; Dyrskog, S.E.; Agger, A.; Gregersen, S.; Colombo, M.; Xiao, J.; Hermansen, K. Can stevioside in combination with a soy-based dietary supplement be a new useful treatment of type 2 diabetes? An in vivo study in the diabetic goto-kakizaki rat.Rev. Diabetes Stud. 2006, 3, 189-199. [CrossRef] [PubMed]

44. Abudula, R.; Jeppesen, P.B.; Rolfsen, S.E.; Xiao, J.; Hermansen, K. Rebaudioside a potently stimulates insulin secretion from isolated mouse islets: Studies on the dose-, glucose-, and calcium-dependency. Metabolism 2004, 53, 1378-1381. [CrossRef] [PubMed] 
45. Evans Kreider, K.; Pereira, K.; Padilla, B.I. Practical approaches to diagnosing, treating and preventing hypoglycemia in diabetes. Diabetes Ther. 2017, 8, 1427-1435. [CrossRef] [PubMed]

46. Ortiz, M.R. Hypoglycemia in diabetes. Nurs. Clin. N. Am. 2017, 52, 565-574. [CrossRef] [PubMed]

47. Thrasher, J. Pharmacologic management of type 2 diabetes mellitus: Available therapies. Am. J. Cardiol. 2017, 120, S4-S16. [CrossRef] [PubMed]

48. Vennekens, R.; Mesuere, M.; Philippaert, K. Trpm5 in the battle against diabetes and obesity. Acta Physiol. 2017. [CrossRef] [PubMed]

49. Kim, M.S.; Pinto, S.M.; Getnet, D.; Nirujogi, R.S.; Manda, S.S.; Chaerkady, R.; Madugundu, A.K.; Kelkar, D.S.; Isserlin, R.; Jain, S.; et al. A draft map of the human proteome. Nature 2014, 509, 575-581. [CrossRef] [PubMed]

50. Fonfria, E.; Murdock, P.R.; Cusdin, F.S.; Benham, C.D.; Kelsell, R.E.; McNulty, S. Tissue distribution profiles of the human trpm cation channel family. J. Recept. Signal Transduct. Res. 2006, 26, 159-178. [CrossRef] [PubMed]

51. Philippaert, K.; Pironet, A.; Mesuere, M.; Sones, W.; Vermeiren, L.; Kerselaers, S.; Pinto, S.; Segal, A.; Antoine, N.; Gysemans, C.; et al. Steviol glycosides enhance pancreatic beta-cell function and taste sensation by potentiation of trpm 5 channel activity. Nat. Commun. 2017, 8, 14733. [CrossRef] [PubMed]

52. Buteau, J.; El-Assaad, W.; Rhodes, C.J.; Rosenberg, L.; Joly, E.; Prentki, M. Glucagon-like peptide-1 prevents beta cell glucolipotoxicity. Diabetologia 2004, 47, 806-815. [PubMed]

(C) 2018 by the authors. Licensee MDPI, Basel, Switzerland. This article is an open access article distributed under the terms and conditions of the Creative Commons Attribution (CC BY) license (http://creativecommons.org/licenses/by/4.0/). 